\title{
Vegetation cover indexes in urban areas: Landscape Ecology studies with Sentinel2 images
} Índices de cobertura vegetal em áreas urbanas: estudos de Ecologia da
Paisagem com imagens Sentinel2

\author{
Ana Clara Mourão Moura ${ }^{1}$ \\ Nicole Andrade da Rocha ${ }^{2}$ \\ Ítalo Sousa de Sena ${ }^{3}$ \\ Xeni Kechagioglou 4 \\ Michele Campagna ${ }^{5}$
}

Recebido em abril de 2018.

Aprovado em novembro de 2018.

\begin{abstract}
The paper defends the importance of access to data, as Copernicus Project that allows the use Sentinel satellite images to map land use. It puts emphasis in vegetation cover, using metrics of Landscape Ecology, mainly the edge effect, to measure the relation between built and green landscape in urban areas. Develops case studies in European cities and criticizes the rankings that don't consider specific local conditions. It points out the possibilities of using some metrics based on Landscape Ecology to analyze the balance between built and green landscapes, as a support to propose new urban indexes, with relative values according to local characteristics.
\end{abstract}

KEYWORDS: Urban Green Areas. Sentinel-2. Landscape Metrics.

\section{RESUMO}

Defende a importância do acesso a dados, como os do Projeto Copernicus, que permite o uso de imagens do satélite Sentinel para mapeamento do uso do solo. Apresenta o mapeamento da cobertura vegetal e o uso de métricas

\footnotetext{
${ }^{1}$ Escola de Arquitetura da UFMG, Laboratório de Geoprocessamento. Programa de Pós-graduação em Geografia e Programa de Pós-Graduação em Arquitetura e Urbanismo, Brasil. E-mail: anaclara@ufmg.br

${ }^{2}$ Escola de Arquitetura da UFMG, Laboratório de Geoprocessamento. Programa de Pós-Graduação em Arquitetura e Urbanismo, Brasil. E-mail: nicarocha.jf@gmail.com

3Instituto de Geociências da UFMG. Programa de Pós-graduação em Geografia, Brasil. E-mail: italosena@gmail.com

${ }^{4}$ Università Degli Studi di Cagliari, PhD Candidate, UrbanGis Laboratory, Itália. E-mail: xeni@unica.it 5Università Degli Studi di Cagliari, UrbanGis Laboratory, Itália. E-mail: campagna@unica.it
} 
da Ecologia da Paisagem, com destaque para o efeito de borda, para medir a relação entre áreas verdes e áreas edificadas urbanas. Desenvolve estudos de casos em cidades europeias e critica os "rankings" que ignoram condições locais específicas. Ressalta as possibilidades de uso de métricas com base na Ecologia da Paisagem para analisar o equilíbrio entre paisagens edificadas e áreas verdes, como suporte para novos índices urbanos que considerem valores relativos e que estejam mais a tom com as características e valores locais.

PALAVRAS-CHAVE: Áreas Verdes Urbanas. Sentinel-2. Métricas de Paisagem.

\section{Introduction}

The act of measuring built and natural land uses to arrive to indexes is part of the main studies that researchers do, with the goal to characterize, compare and define vulnerabilities and attractiveness in space. With the support of IT tools and GIScience with conditions to propose and test models, we are always producing or using indexes. With the goal to understand the relation between variables in a systemic approach, we produce analysis and synthesis, with methods based on decompose, compose and recompose proposed by McHarg (1969) in "Design with nature" (Figure 1).

Figure 1 - Principals in Techonologies of Geoinformation

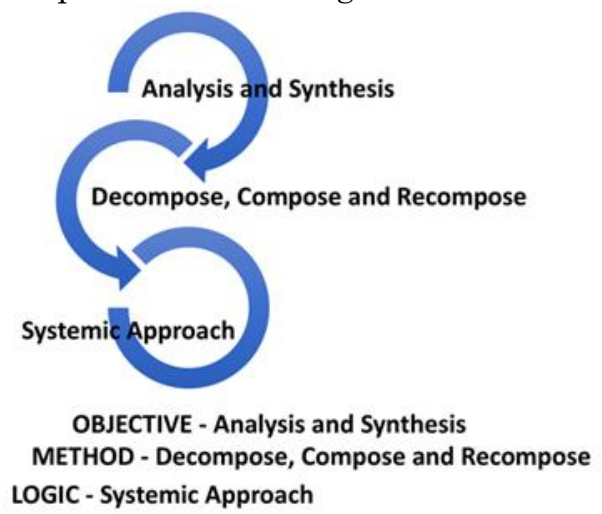

Source: Prepared by the authors.

Access to spatial data is becoming more and more possible, although with huge territorial differences related to economic inequalities, lack of policies and awareness of the role of data in planning. Data can be 
transformed into information using models, based on the representation of vulnerabilities and attractiveness of the areas. The construction of knowledge is base to the societal development because the people of the place will be able to recognize their reality and to be more critical about plans and policies, in a process of education with the use of data and information.

In the vegetation cover field, there are some classical references mentioned by most of the researchers. A rooted and widespread index in Brazil is the value of $12 \mathrm{~m}^{2}$ of green area/inhabitant, considered ideal, assigned to the UNO, OMS or FAO. Cavalheiro e Del Picchia (1992) put in discussion if this index was really proposed by any institution, and if they are to be applied, they must refer only to parks or public area categories for outdoor recreation.

In face of those values, Brazilian Society of Urban Arborization (SBAU) proposed a minimum index for public green areas for recreation of $15 \mathrm{~m}^{2} /$ inhabitant (SBAU, 1996), but separating these specific areas with infrastructure for recreation from general vegetation cover and free empty spaces. So, there's something more to put under discussion: the definition of green infrastructure and the mapping of vegetation cover.

It's also very common, from the begging of the use of spatial models up to recent possibilities in GIScience, the use of ranks to compare situations around the World. We can use as an example, the studies that use rankings that classify the cities more and less green as "Green City Index", developed the Economist Intelligence Unit, sponsored by Siemens (DENIG, 2012) and the "Treepedia's Green View Index", developed by MIT's Senseable City Lab and conducted by Ratti (SEIFERLING et al., 2017, LI et al., 2015).

In the studies about "Green City Index" they arrive to general rankings in each continent, as the goal is an economic study, but at least they use different variables according to local conditions and classify the performances of each variable according to local references. Each city receives an overall index ranking and a separate ranking for each individual category. To countries that have good data, they present the results numerically, but to 
other countries, they classify it in five performance bands from "well above average" to "well below average" (for the Asian, Latin American and African Indexes). This study is an example of the importance of data in analysis, as inequalities of basic information results in comparisons that can be questioned. They also recognize that classifications and rankings must follow local references.

In studies of "Treepedia's Green View Index" the goal is to define which cities have the greenest streets, using data collected from Google Street View. It quantifies how green a street view looks, according to the number of trees it contains. They say the result is a scalable and universally applicable method to analyze the amount of green perceived while walking down the street. We question the concept of "universally" that doesn't consider cultural values and specificity.

From the necessity of searching for parameters, there is the trick of comparing what is not comparable. Rankings can be very generalist, and serve for specific purposes. But, on the other hand, we must recognize that they can call attention to problems that must be faced. Urban planners are always searching for parameters that can provide a reference to life quality. This is the base of a Master Plan: to recognize values from a society, as a collective goal or limits of what can be accepted, according to a shared decision. But it's important to understand that the rate of permeability, the only urban parameter presented in Master Plans and Laws of Land Use and Occupation, is not exactly green areas. They are important to face the problems of regulating the capture of rainwater or to promote ambiance and aesthetic values, but they are not green areas (Figure 2).

Figure 2 - Projection of permeability areas in urban lots 


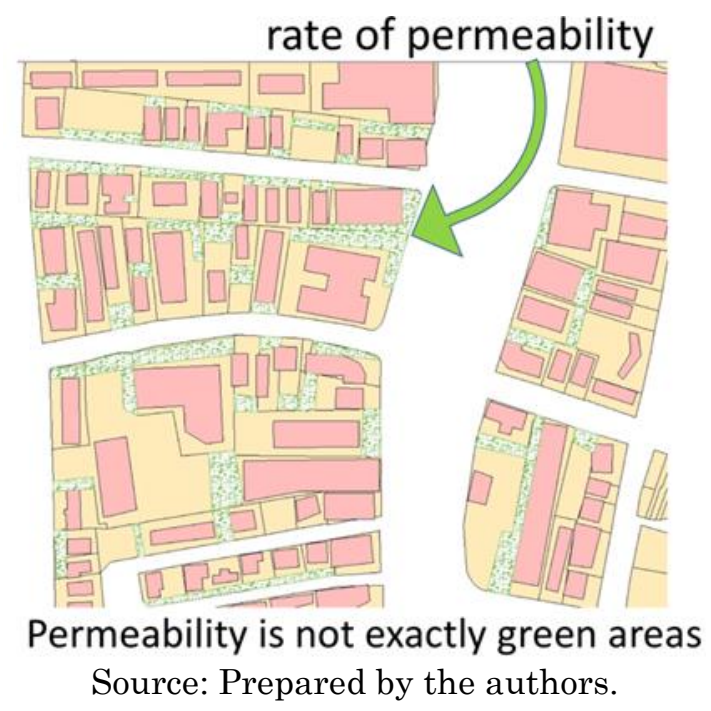

The "environmental quota" (Quota Ambiental, Decree No. 57565, December 2016), such as in São Paulo's Strategic Master Plan (PDE 2014), is not enough to face the urban needs for green areas. (PREFEITURA MUNICIPAL DE SÃO PAULO, 2014, 2016). (Figure 3). It's an important parameter to face the needs of rainwater drainage in cities where free areas were not left without impermeability, but it's quite limited when the interests are environmental ambience and the presence of green areas in urban life. In most of Brazilians master plans, permeability is the only parameter required, and in most building codes ("Código de Edificações", also known as "Código de Obras") the only requirement is to plant one tree on the sidewalk, sometimes controlling it's minimum height and the selection of native species.

Figure 3 - The "environmental" quota in São Paulo, according to Strategic Master Plan, Decree 57565/2016. In green the studies to apply rate of permeability in the lots. 


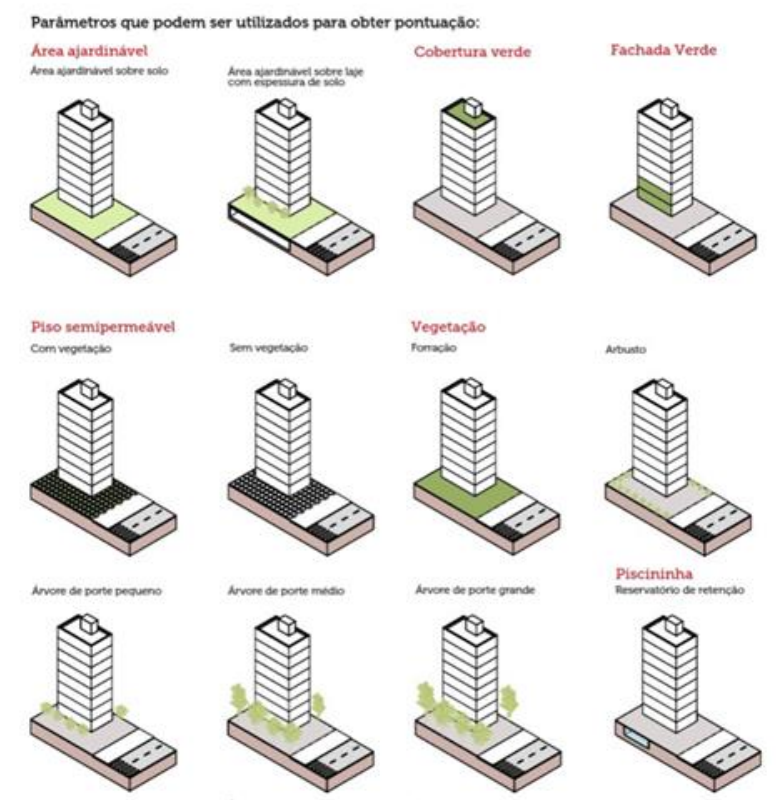

Source: Prefeitura Municipal de São Paulo (2016), in: http://www.camara.sp.gov.br/zoneamento/dicionario/

This paper has the goal to show the importance of free access to data, as support to the construction of information, based on models. It defends that the production of information and the promotion of knowledge must review the way we work with indexes. It tests and presents some general indexes, to criticize the indiscriminate use of comparisons between very different realities. Classifications must be more relative than absolute, considering different realities and avoiding basic spatial mistakes, like the use of administrative limits in the model's analysis or generalized indexes that uses rigid limits as references. It is also a first step to study urban parameters related to green areas that can be included in urban Master Plans. Complementary studies that are under development are working with the relation between volumetric buildings and volumetric vegetation cover (Rocha et al., 2017) with the goal to create references to propose relative and local rates to be reached by plot, as an equilibrium and compensation of building volumes (Figure 4).

The present study focuses on bidimensional values and analysis, easier to calculate and to measure in the city, mainly with the advent of easy access to satellite images, constantly updated and free. Also bidimensional 
references, resulted from the projection of green areas, can be a first step to be applied as parameters to promote the green uses in cities. Using satellite imagery and producing NDVI (Normalized Difference Vegetation Index), it's possible to analyze the relation of the main built fragment and its surroundings, comparing to vegetation cover, according to local reference, avoiding indiscriminate rankings.

Figure 4 - Vegetation volume studies.

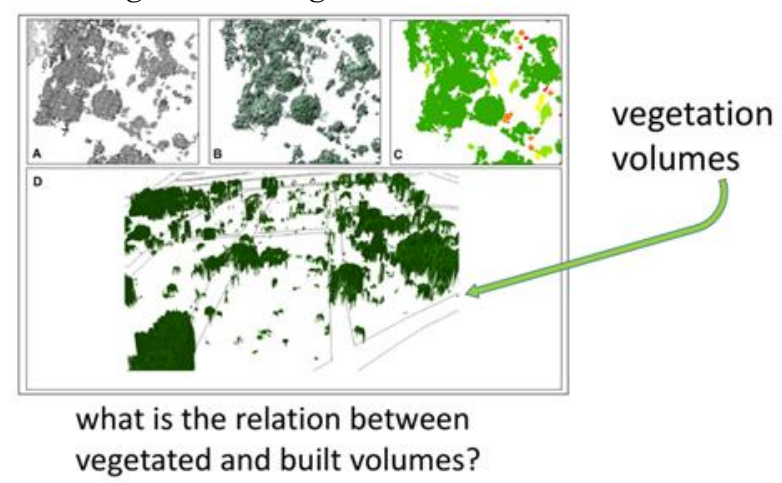

Source: Rocha et al. (2017).

\section{Interpretation of Shapes in Land use According to Landscape Ecology}

Metric studies, according to Landscape Ecology, aims to understand, through the shapes, the relation between the fragments and its surroundings. These studies can be applied in the green urban context, searching to identify the ideal conditions of uses in the city. The application of landscape metrics aims to select the most appropriate fragments for environmental preservation and to compose the spatial arrangements to achieve biodiversity, the balance of species and the gene flow, involving the study of patterns and the interaction between patches within the landscape mosaic (FORMAN e GODRON, 1986; METZFER, 2001; COUTO, 2004; ROCHA et al., 2016).

According to Landscape Ecology, the ideal fragment has a good shape index, big enough to present a protected core, and not far from other fragments to conform an ecological corridor. Some fragments don't satisfy all 
conditions but may play a specific role in fragments network (FORMAN e GODRON, 1986).

The main metrics for urban studies are: core area, inscribed circle, border effect, size, shape index, degree of isolation and connectivity between fragments (ROCHA et al., 2016).

For this study, we used the metric "edge effect", which makes it possible to calculate the fragment shape index, whether it has many branches or it is more compact. It is measured by the relation of perimeter/area, to indicate the complexity of the shape. The bigger the relation perimeter/area is, the more significant the contact is between different uses in the borders (Figure $5)$.

Figure 5 - Edge effect metric

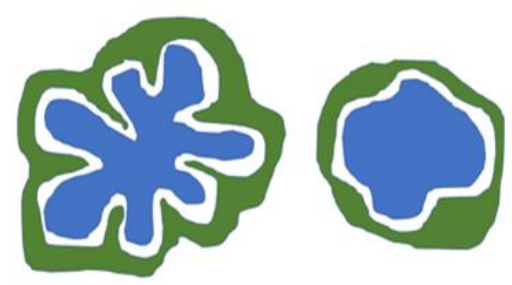

Source: Prepared by the authors.

The idea was to recognize the compactness of the main fragment in urban use and the anthropized landscape with lack of vegetation cover. The bigger and the more compact the main fragment of building area without vegetation is, the less vegetation cover is related to the daily lives of citizens. If the main fragment of built areas has more borders and is less compact, with edges in contact with vegetation cover, the closer the green areas are to the daily lives of citizens.

\section{Material and Methods}


To illustrate the discussions, it presents the case studies of Nice (France), Cagliari (Italy), Athens (Greece) and Prague (Czech Republic). The selected cases are with different urban conditions, as different dimensions (from medium to big cities), different types of urbanization (from spread to concentrate) and different area compositions (from cities with very big municipality areas and empty sectors without urban use, to those that urban use corresponds to the totality of municipality area), with different proportions of green areas.

All of the case studies are touristic places in four different countries in Europe. Nice, Cagliari and Athens are coastal cities, but Nice and Cagliari are middle size cities associated to the idea of good urban environmental quality, while Athens is a huge city, but with lack of green areas. Prague is also a big city, with a very big population, but it's very spread and is characterized as a very green city. Prague is a reference for "best practices" in the distribution of green areas, in many typologies of uses and very well distributed along the built area. The idea was to analyze the performance of the methods in different conditions and to discuss the possibilities of applying this analysis to characterize the presence of green areas in the cities and, in a next development of the researches, to propose urban parameters related to green plots to be proposed to Master Plans.

Copernicus Sentinel data was used, from the European Space Agency's (ESA) Sentinel-2 mission. Sentinel-2 images are captured by a satellite equipped with an MSI (multi-spectral instrument), a sensor which generates data in 13 spectral bands, from which the bands of $10 \mathrm{~m}$ resolution were used: 2, 3, 4 and 8. They were worked in visual composition (RGB432) and near infrared composition (RGB843) to highlight vegetation cover. NDVI (Normalized Difference Vegetation Index) was calculated and classified according to 4 types of land use, using local references for the value ranges: (a) Without vegetation, composed by exposed soil, buildings, water or shadow; (b) Buildings and/or low occurrence of vegetation, grass; (c) Buildings and/or 
occurrence of medium vegetation, scrubby; (d) Dense vegetation, mainly woody, robust.

Once land use maps were produced, metric studies were applied, beginning from identifying the main built fragment in the municipality. The metrics of each fragment were calculated, composed by the total area of each land use typology, main built fragment perimeter, main built fragment relation perimeter/area, the administrative limits area, relations between built and green fragments and population density relations.

With the analysis of edge effect metrics, based on forms and resulted from report perimeter/area, intend to identify if the main built fragment (the "core" of the urban area) is characterized by a very compact urban area with concentrated green areas, or with a spread urban plot with distributed and integrated green areas. The study proposes the use of some simple metrics based on edge factor (perimeter/area) of main urban fragment, which is compared to the distribution of vegetation fragments.

The first step was to do the composition RGB-432, using the visual bands, to provide a view from reality. The other composition was the RGB843 , using part of visual range and the infra-red band, to highlight the vegetation in false color. The second step was, using the red and the infra-red bands, that in Sentinel-2 area the bands 4 and 8, the NDVI (Normalized Difference Vegetation Cover) was composed.

From NDVI ranking, that goes from -1 to +1 , four components of legend were defined, using "natural breaks" logic, to identify the spatialization of levels of vegetation and, mainly, the identification of the main plot of built urban area without vegetation. After that, was identify the main fragment of built areas, to apply the edge effect metric was calculated, the report perimeter/area and the measures related to it.

\section{Development - Case Studies in European Cities}


As result, working with the analysis of a limited number of metrics, it was possible to have expedited results that characterized the cities according to a general condition of built areas in comparison to green areas, and mainly the interrelation and proximity of built and green areas.

\subsection{Athens}

Observing the first case study, Athens, in Greece, we understand that the city has a very high dense urban area with a lack of green areas. The city of Athens had a population of 664046 inhabitants in 2011 (Hellenic Statistical Authority), but the plot of the city is conurbated with other cities in the metropolitan area, composed by 7 districts and 58 municipalities, in a total of $3,737,550$ inhabitants. That way, we decided to work only with the city of Athens, as we were going to work only with the main cities in the other examples, without considering the conurbated area. The result the composition RGB-432 and RGB-843 in red color (Figure 6A) it's possible identify in red color the existent green areas and the NDVI calculation (Figure 6B).

The case study of Athens helps us to understand the problem of working with administrative boundaries in the analysis. They are political and administrative lines that are used in most studies and rankings, but they don't consider geographic, demographic and social changes that compose specific characteristics of the area. It's a way to demonstrate the problems of working with absolute way of thinking and not in relative way of thinking.

If Athens had a bigger delimited official area, the numbers could change completely in the results about the relation of green areas per municipality. The position of Athens in a rank should be according to a reference that is not administrative delimitation, and for that reason it's possible to say that a ranking using this reference is not suitable. To 
understand and to study Athens more appropriately, we should study it as a conurbation area, in metropolitan territory.

Figure 6 - Case study of Athens. A - Composition RGB-432 (visible composition) and RGB843 (using infra-red to highlight vegetation cover). B - NDVI calculation

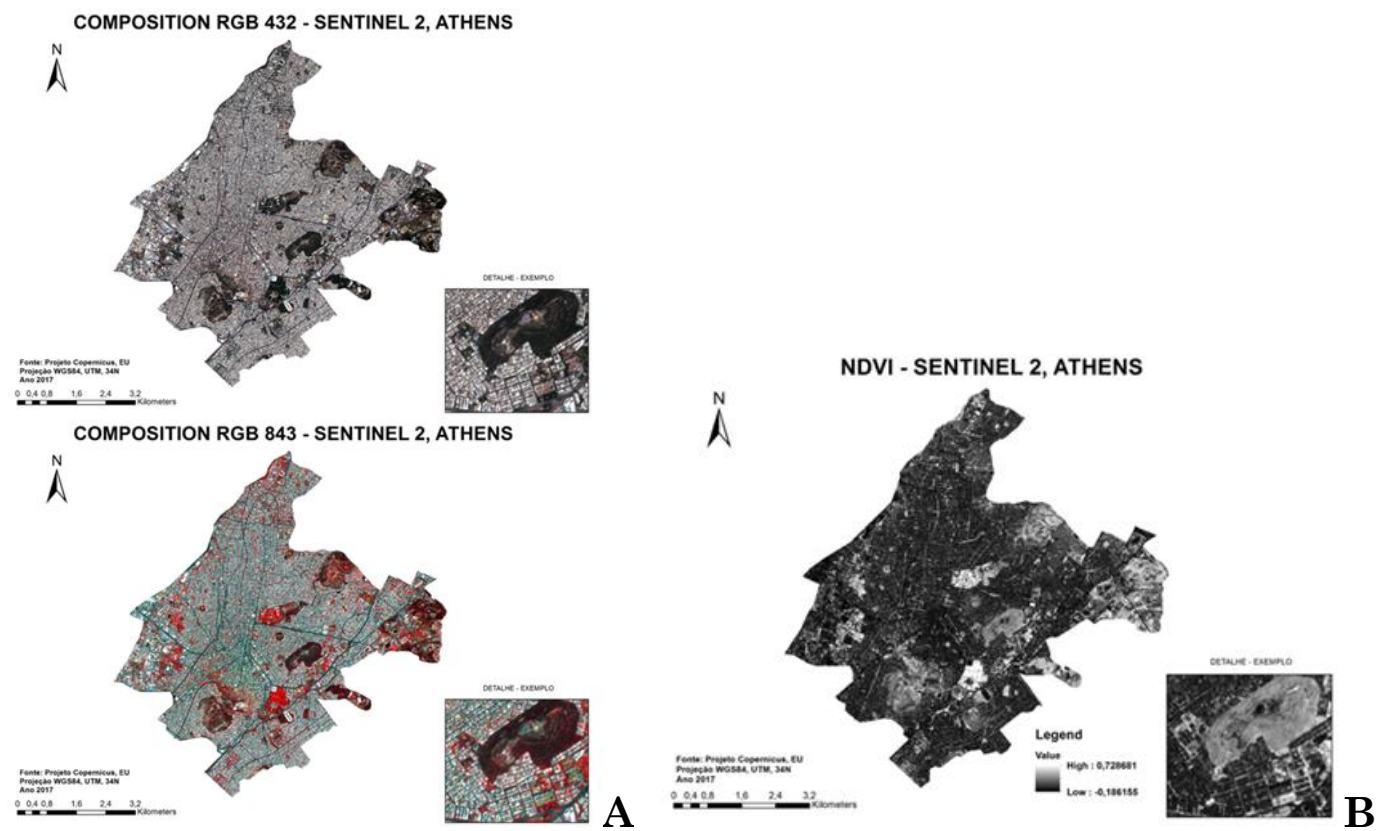

Source: Prepared by the authors.

rom NDVI it was identified the areas without vegetations (Figure 7A) and the main fragment with "edge effect' (Figure 7B) and your relationship between built areas and green areas.

Figure 7 - The classification of NDVI. A - From "no vegetation" to "dense vegetation". B - The main built fragment and the analysis of edge effects metrics

Rev. Bras. de Cartografia, vol. 70, Edição Especial "XXVII Congresso Brasileiro de 


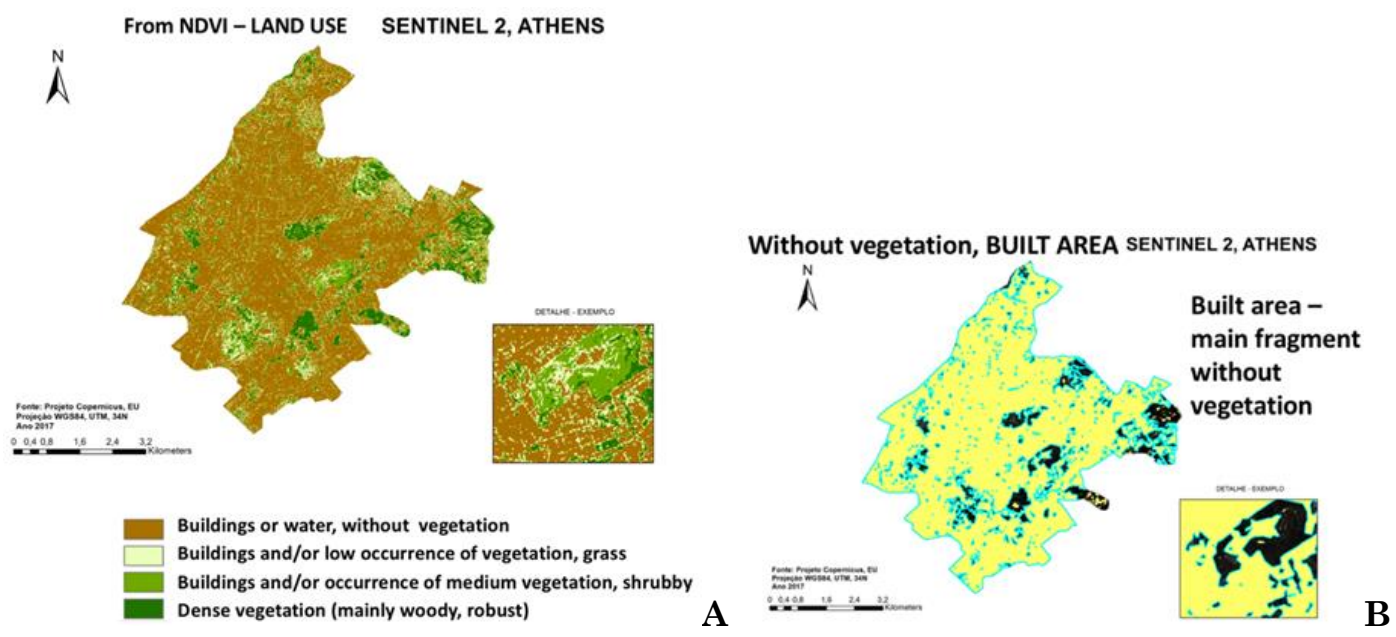

Source: Prepared by the authors.

\subsection{Cagliari}

In the case study of Cagliari, in Sardinia, the difficulties to apply the method was related to water, that is classified in NDVI together with urban areas without vegetation, as the index is to tell about the presence of vegetation, and both water and built areas can be in the same condition. But it's very interesting to see different colors in the water, due to the possible presence of organic materials and vegetation in some parts of the sea bay. The was interesting to show the importance of doing the compositions in visible bands (RGB-432) and also using infrared to highlight the vegetation (RGB843), and to analyze them. In some parts, in which the visible composition presents the green colors in visible composition making the observer believe it's a green area, the infrared composition allows to recognize it as water and without vegetation (Figure $8 \mathrm{~A}$ ).

From NDVI and its classification in 4 types of land use, according to vegetation, it's possible to observe that urban morphology resulted in very good landscape quality. The urban plots are surrounded by vegetation of different types of water (Figure 8B).

Figure 8 - Cagliari case study. A - RGB-432 and RGB-843 composition. B - NDVI and the classification of land use according to the presence of vegetation. 

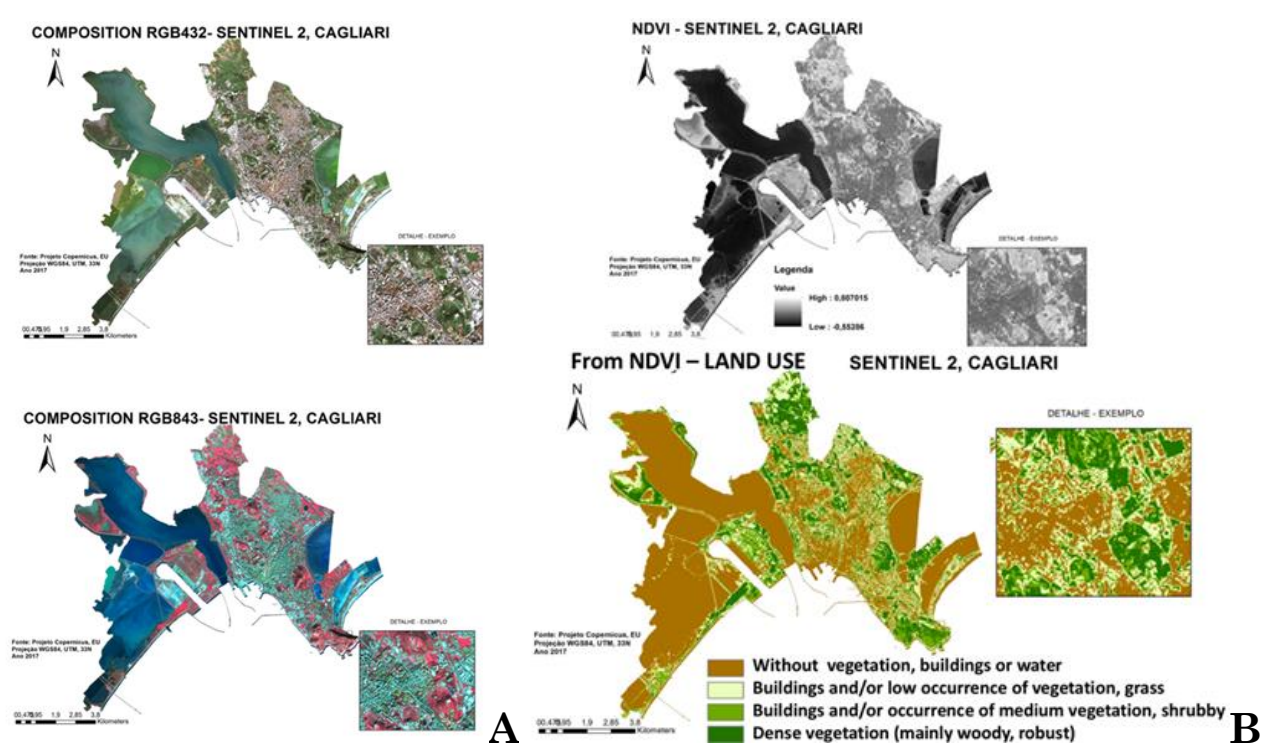

Source: Prepared by the authors.

In Cagliari case study, as the urban plot is spread and not concentrated, there not just one main fragment of built area, but some plots, some fragments. To apply the method, it required the selection of the main fragment. In cases like that it's indicated to choose the one with the biggest area, the oldest occupation (were the city was born), the denser (were the city is still very dynamic) and the more central fragments.

The main urban plot, that means the conurbated urban area, is very irregular and has a very high relation perimeter/area. It means that there are more surfaces of contact between urban land use and other uses, creating a more heterogeneous landscape and allowing people to have more contact with green and blue areas in their daily lives (Figure 9).

Figure 9 - The main built area and its morphology in contact with vegetation and water 


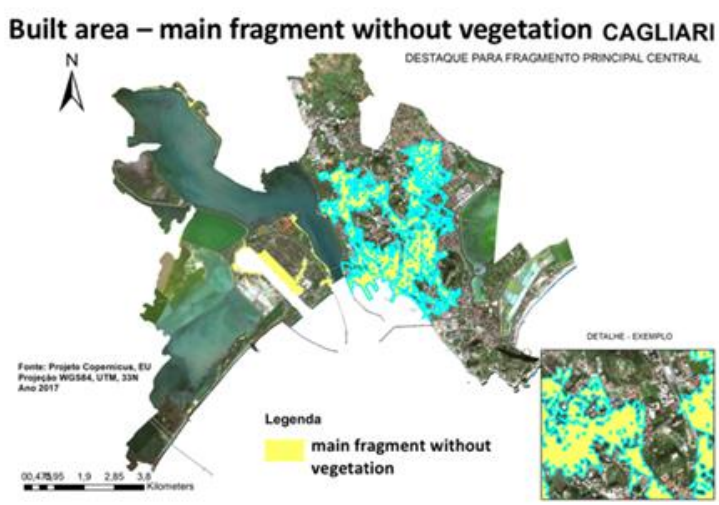

Source: Prepared by the authors.

\subsection{Nice}

The case study of Nice, in France, was important to understand the meaning of analyzing main urban fragments. We applied the same logic as Cagliari, but in Nice there were two main fragments, very dense ones, with very similar areas. In this case, the selection was for the most traditional part, because both of them have strong dynamics, as they constitute of old town and new town.

Nice's urban area, due to geographic definitions by topography and the sea, was constructed in two parts, almost with the same dimension. We took the oldest plot to analyze, because it's a little bit bigger and because we wanted to analyze the traditional city (Figure 10A).

Different from Cagliari, the urban main fragments are very compacted and not spread, with low values in the report of edge effect. As a result, green areas are not so present in daily life, but they are out of main urban plots. This case study was interesting to prove that if a rank was constructed, we could not see this condition, because when using the municipality limits, the report is positive despite the total green area and urban area, even thought people are not served by green areas in contact with urban areas. (Figure 10B).

Figure 10 - Nice case study. A - RGB-432 and RGB-843 compositions in Nice. B - Land use according to the presence of vegetation and definition of main built area, to be analyzed as edge effects and the contacts with green areas. 


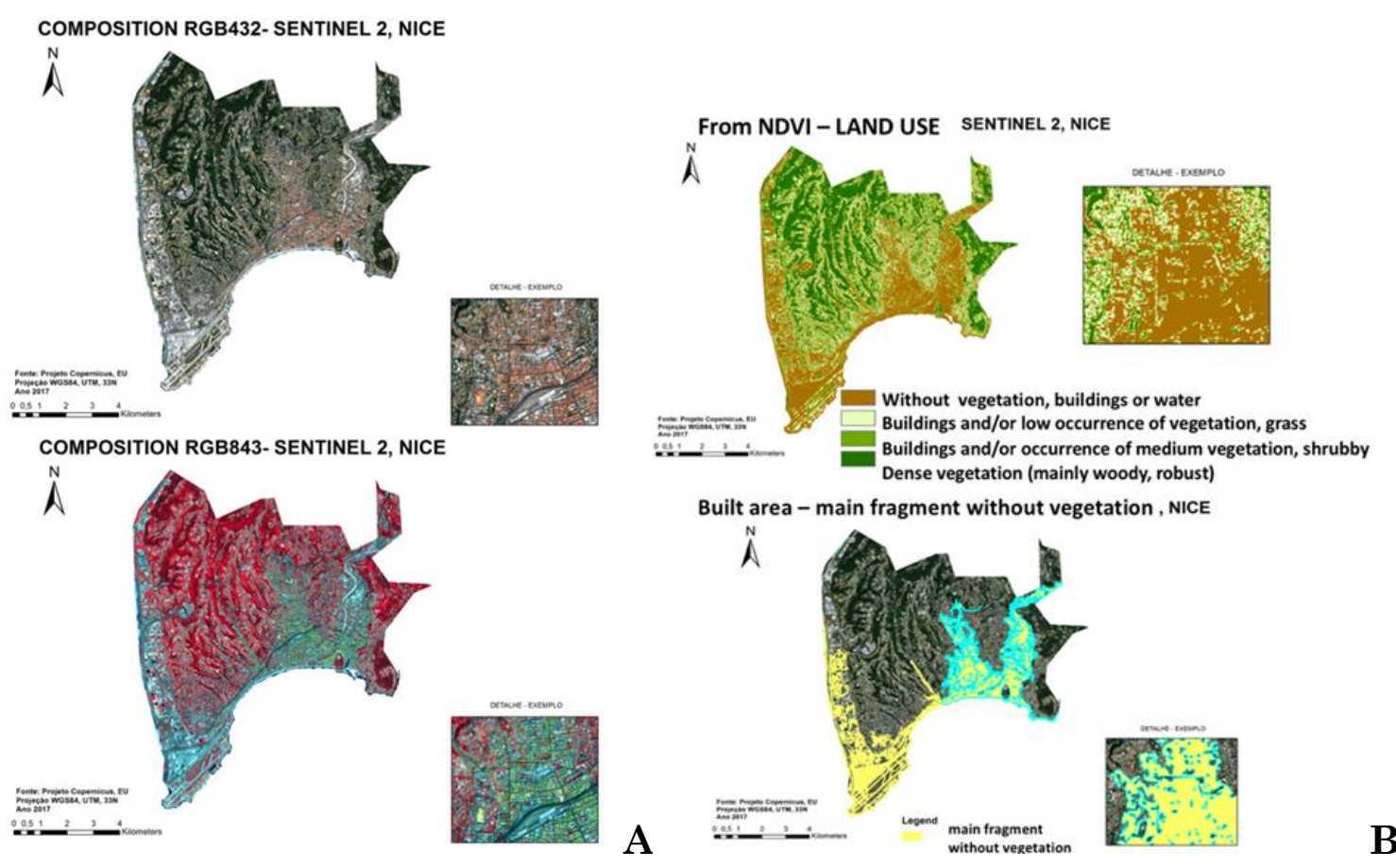

Source: Prepared by the authors.

\subsection{Prague}

Finally, the case study of Prague, in Czech Republic. Prague has a big municipality area, which interferes completely in any index or ranking that can be constructed. The proportion of urban area and green areas in the municipality is conditioned to this very big territorial dimension (Figure 11A). From the composition using infrared band it's possible to see that the river is a very important element the cuts the municipality and cuts the main central area. As water in NDVI is classified together with dense built area, as both don't have vegetation, it will require the use of the shape of water to cut the urban plot and separate it from the river (Figure 11B).

Figure 11 - Case study of Prague. A - RGB-432 and RGB-843 compositions. B - NDVI and land use classification. 

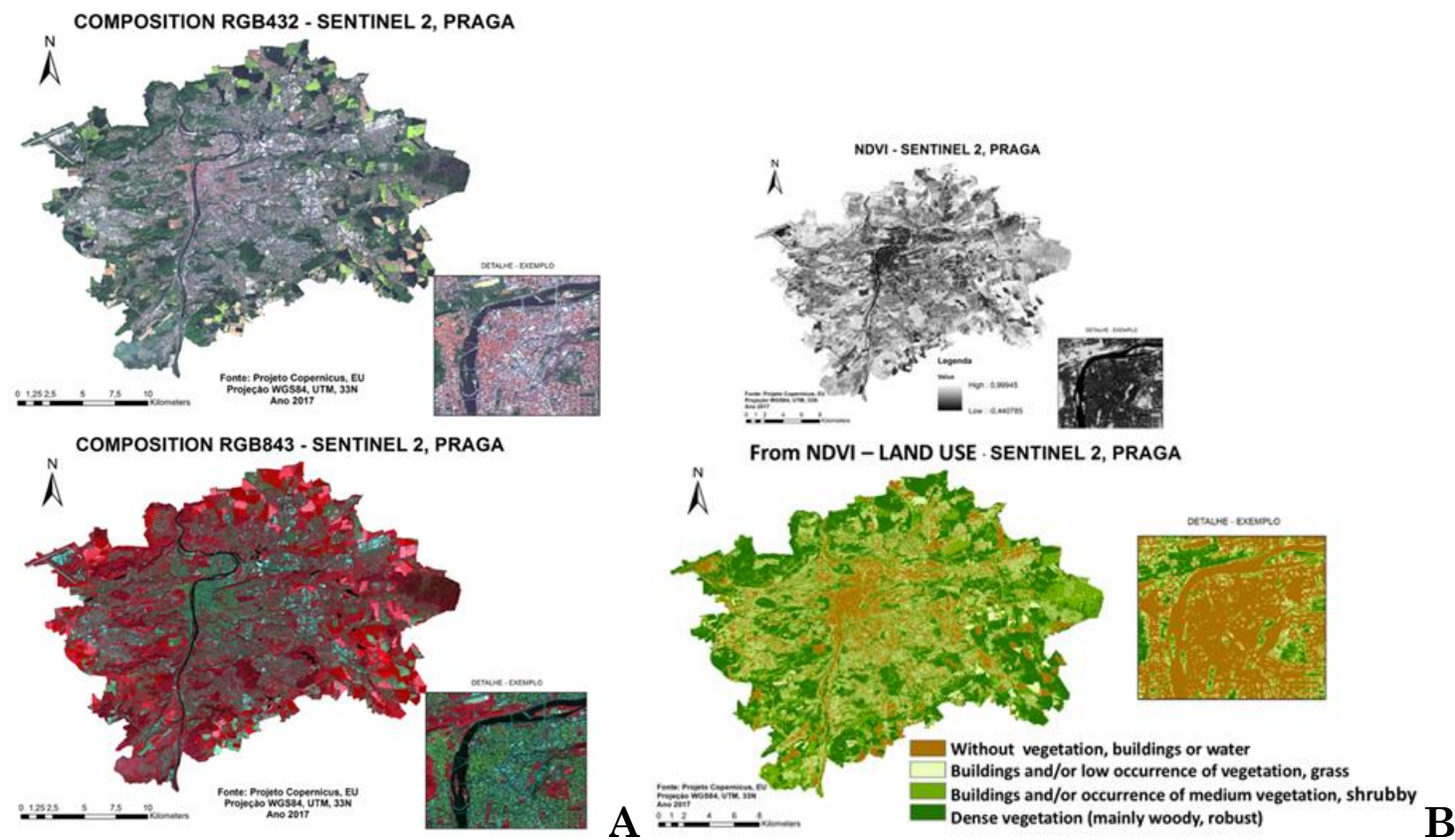

A

Source: Prepared by the authors.

There are many urban plots, which are considered very good, because the urban area is not densified and condensed, resulting in built areas very connected and integrated with vegetation and with the river.

\section{Results: Comparison between Athens, Cagliari, Nice and Prague}

Traditional methods of calculating areas, population numbers and comparing values can also be interesting to discussions about generalizations and rankings. Some general values are important to understand the dimensions and characteristics of the case studies, but the simple comparisons without considering specificities of each one can conduct to misunderstandings. Since the beginning of this paper we are advocating for the risks of rankings and for the use of comparisons in relative and not in absolute mode.

Comparing the graphics with values from the 4 cities, the first surprise is that Prague has an urban area bigger than Athens, but Athens has a main urban plot bigger than Prague. The perimeter of main fragment and urban area in Prague is much bigger that the perimeter from Athens, which means 
that they are as big as each other in urban area, but just by this metric it is possible to understand that Prague presents a morphology that is not compact and it's more spread in the territory. In the relation perimeter/area, Prague has a much more expressive condition than Athens, but Cagliari appears almost as good as Prague. Studies about the spread, compactivity or the contact with other land uses area possible due to these metrics we tested, which makes the analysis much more interesting than just general values of areas (Figure 12).

Figure 12 - Urban Area, Urban Perimeter, Edge factor in urban areas, Main Urban Fragment. Graphics about Athens, Cagliari, Nice and Prague.

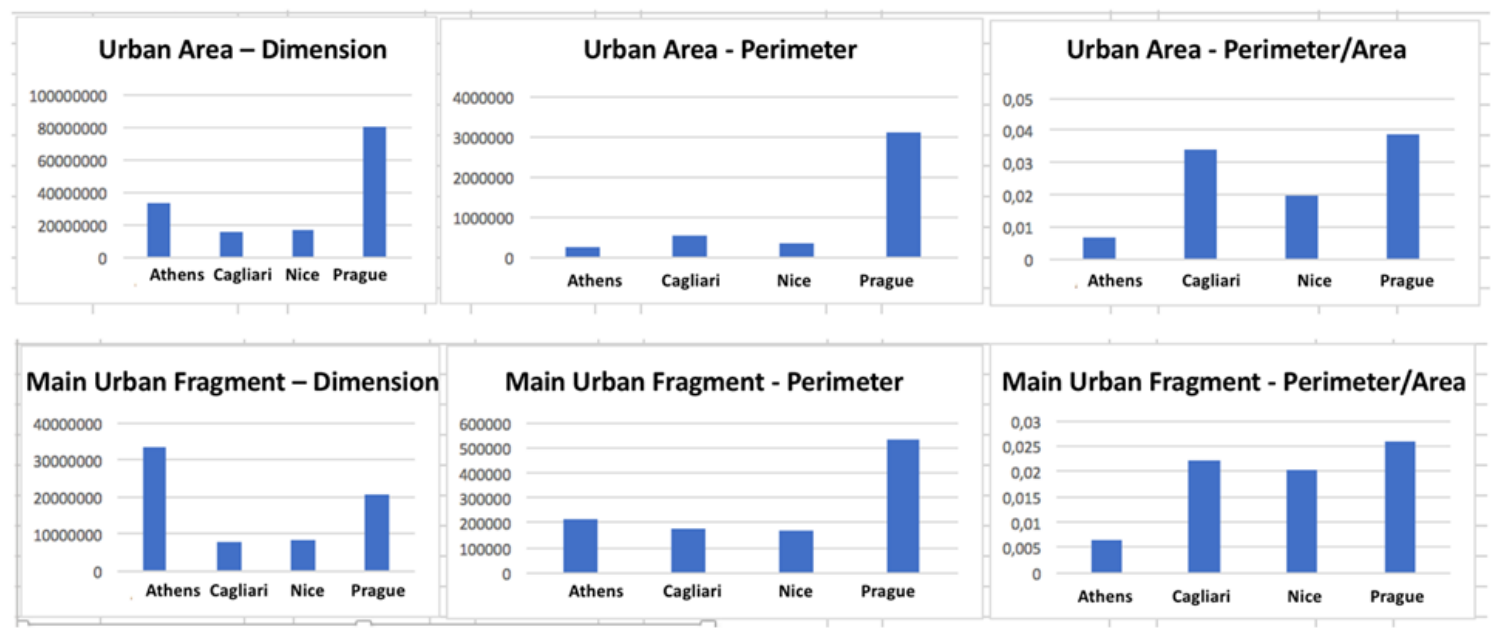

Source: Prepared by the authors.

Athens surely presents the worst condition, because it has the biggest area in main urban fragment, the smallest perimeter as the entire municipality, a small perimeter as main urban fragment and the smallest ratio perimeter/area. It's a very compact and big city, mainly in its center urban fragment.

Prague is a big municipality, with a big main urban fragment, but it presents a very big perimeter and a very big ratio perimeter area in the entire municipality and in the main urban fragment.

Graphics with general data about vegetation cover in the case studies demonstrates that Prague has the biggest area in vegetation, the biggest perimeter of these vegetation plots in a general sense all over the 
municipality, but it was a surprise to see that the ratio perimeter/area of the vegetation fragments is the smallest one. It means that the vegetation areas are very compact and delimited. They are spread all over the territory, but they have compact forms. According to the theories of Landscape Ecology, the small ratio perimeter/area means that the plot has less contact with other land uses, and it is more protected and less vulnerable. That's good for the quality and possibility of preserving green areas in Prague (Figure 13).

Figure 13 - Vegetation Area, Vegetation Perimeter, Ratio Perimeter/Area of Vegetation. Graphics about Athens, Cagliari, Nice and Prague.

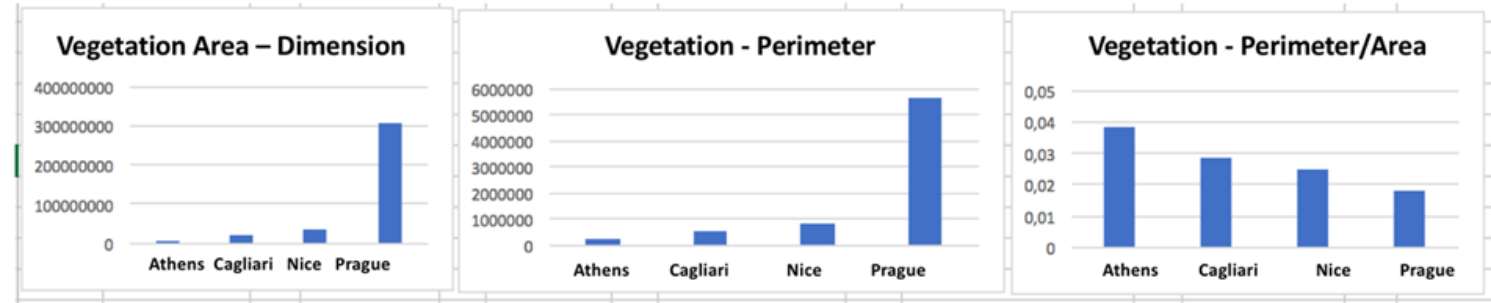

Source: Prepared by the authors.

On the other hand, Athens, that had presented a very compact urban form, with less contacts with green areas and other land uses, presented the biggest ratio perimeter/area in vegetation fragments. They are probably very elongated or have very irregular forms, with smaller core areas. In the same logic presented by Landscape Ecology, they are more vulnerable to changes. The graphics take the sum of all values in the entire municipality and presents a general result. Studies about the fragments, their positions and morphologies could be very interesting to understand the connectivity of the green areas, the insertion of the vegetation in daily life, and the possible destination of the green plots in the city.

Analyzing the graphics about the dimensions of the municipality and the population, we confirm that the territory of Prague is big, while the population of Athens is big for a much smaller area, in a very dense urban land use without green areas. The numbers of Athens are so different that we had to construct another graphic taking Athens out, so that we could compare the 3 other cities. When analyzing just Cagliari, Nice and Prague, we see that 
they are not so different from each other, but the surprise is that Prague has the worst condition in the report in population/green area and Nice appears with a better condition in population/green area and population/municipal area. This is a result that is generally published when studies apply indexes, because they use administrative boundaries, without considering the real use of the space (Figure 14).

Figure 14 - Municipality dimension, Population and Population per area and Population per Vegetation. Graphics about Athens, Cagliari, Nice and Prague

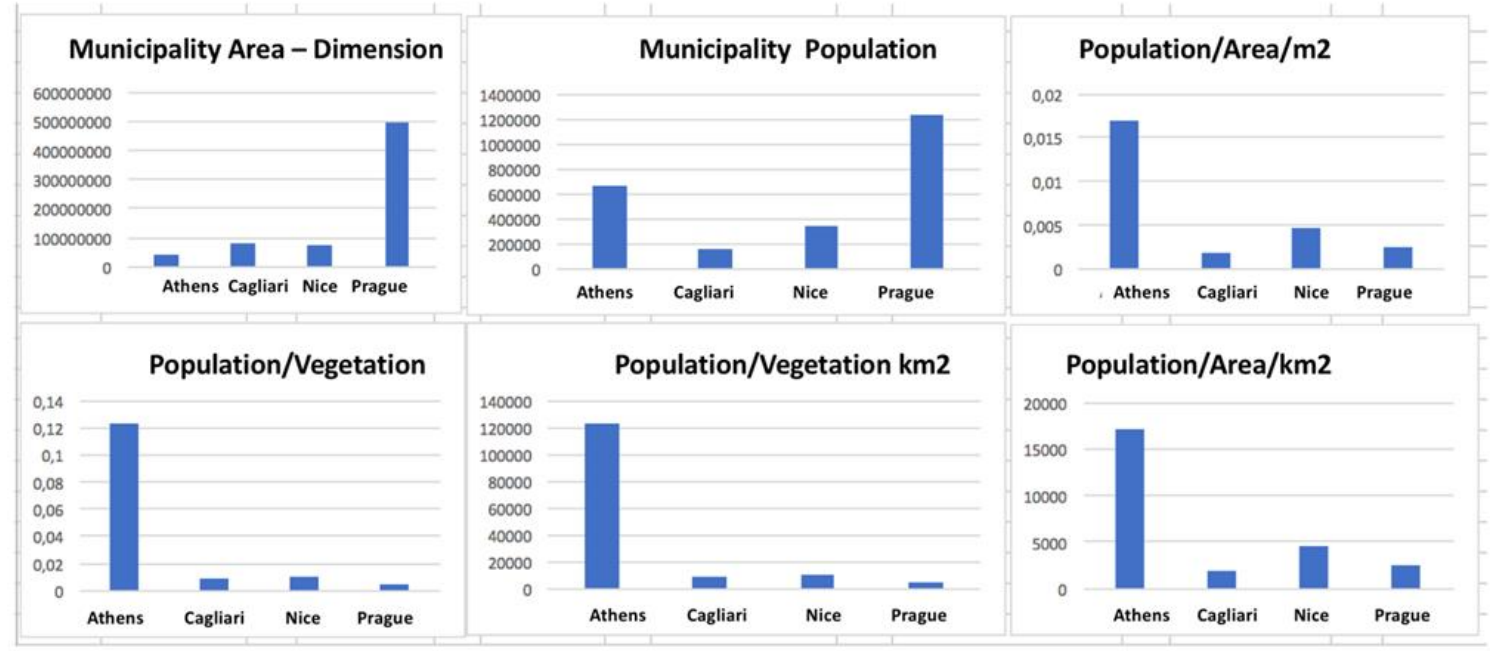

Source: Prepared by the authors.

As Athens presented values much higher than other municipalities, it's interesting to separate it from the examples, to be easier to analyze the performance of the three others without this very different case study. Comparing just Cagliari, Nice and Prague considering the total area of vegetation, the area of administrative limits of the territory and the total of the population, the results presents the risk of analyzing spatial phenomena without considering spatial distribution. The ratio population/vegetation indicates that Nice has the best condition, because it takes the total amount of population and the total amount of vegetation and the ratio population per total area of the municipality. Most of the studies that are written work just like this and present a general index. The studies we developed, using the logic of spatial data and morphology that tells about the integration of green 
and urban areas, demonstrated that Prague presents the best condition and is considered a best practice of green infrastructure, but a general index that is non-spatial, is not able to indicate that (Figure 15).

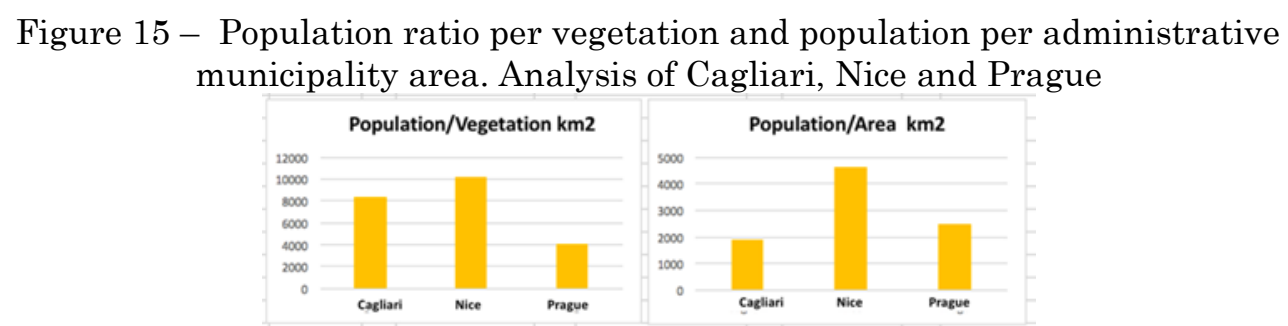

Source: Prepared by the authors.

\section{Discussion}

The idea about this paper was to take conditions of different scenarios to be analyzed and to demonstrate that the use of rankings can be very unproductive and inappropriate. If the goal is just to put the cities, or any other territorial units, in a line from the best to the worst, there is a risk of comparing very different conditions. The ranking can be a way of forcing a delimitation of the individuals according to some defined variables, without recognizing the complexity of variables and the specific cultures and local values. Producing rankings we could lose important information and wrongly compare incomparable conditions.

From the results, it was possible to indicate not a scale of cities from the first to in the last position, but it was possible to interpret the results in relative respecting the specificity of each location and not in absolute way of thinking. This is the way we think metrics and quantitative studies should be: to present values that will help to understand the case study in relative to its own characteristics, considering the value of each specific metric in report to other variables, and to give support to solve local problems or vulnerabilities. 
With the goal to use spatial references to analyze the relation between urbanized and green areas, in the sense of built areas versus vegetated areas, we suggest some other measures that can be obtained with the simple metric of edge effects and areas. The researcher can calculate areas of all the fragments of green areas inside a main built fragment and can produce a report about: number of fragments, standard deviation and average value of areas, and standard deviation and average values of the ratio perimeter/area.

With the values presented in the topic of the graphs with the result of each city of the case study, it was possible to recognize that the first typology for case studies is characterized by a reduced number of fragments and a big standard deviation of areas and of ratio perimeter area, which means that it has very small or very big fragments of vegetation. Very big and very few areas of vegetation cover are not a condition that makes green areas part of daily life in cities. Big parks are visited more rarely than those that are close to peoples' houses or those green areas that are on your way to the places people generally go.

In the case of concentrated green areas, they are not part of the citizen's daily lives, because people need to move to specific areas of the city to have contact with greenery, while the rest of the city is characterized by a very dense built area (Figure 16).

Figure 16 - Edge effect in concentrated green areas: low value in the report perimeter/area in urban areas, and concentrated units of green areas.

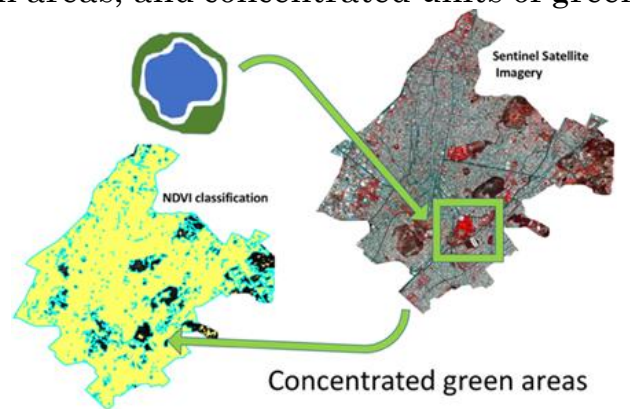

Source: Prepared by the authors.

In the case of distributed and integrated green areas, the main urban plot has a high value in the report perimeter/area, in high edge effect, and its form is amoeboid with extensions, with many holes inside and many parts in 
contact with green areas. In this kind of built and green areas report, the citizens have green areas closer to their home, and are able to get its benefits in daily life, like observing vegetation while going to work, sitting in a park to have lunch, seeing the combination of constructed forms together with natural forms (Figure 17).

Figure 17 - The edge effect in integrated green areas: high value in the report perimeter/area in urban areas, and distributed green areas.

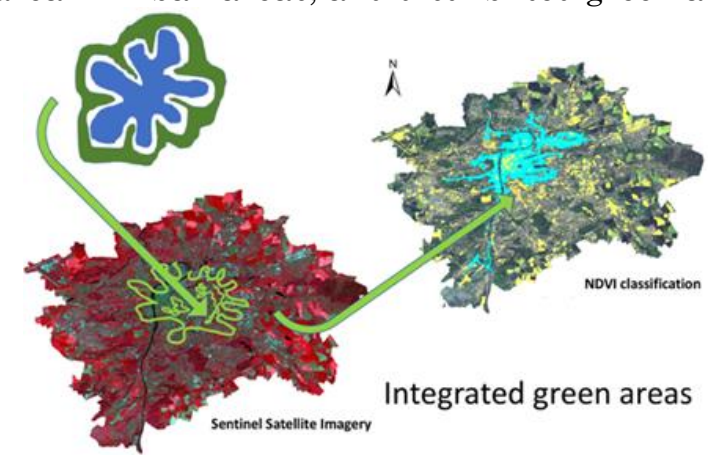

Source: Prepared by the authors.

It's also possible to recognize a second typology that is characterized by a bigger number of fragments and a low standard deviation of areas and of perimeter/area. It means that green areas are numerous and distributed inside the built area, in dimensions that don't work as "islands" in the city but integrated to the landscape. These numerous areas are part of the everyday walking and observation in city and can be developed according to the possibilities of the protection of risks, landscape beauty, climate comfort (Figure 18).

Figure 18 - Studies about the number of fragments of green areas inside built areas, areas and standard deviation of areas of vegetation fragments, ratio perimeter/area and the standard deviation of the ratio in vegetation fragments. Examples of Athens, Nice, Prague and Cagliari 

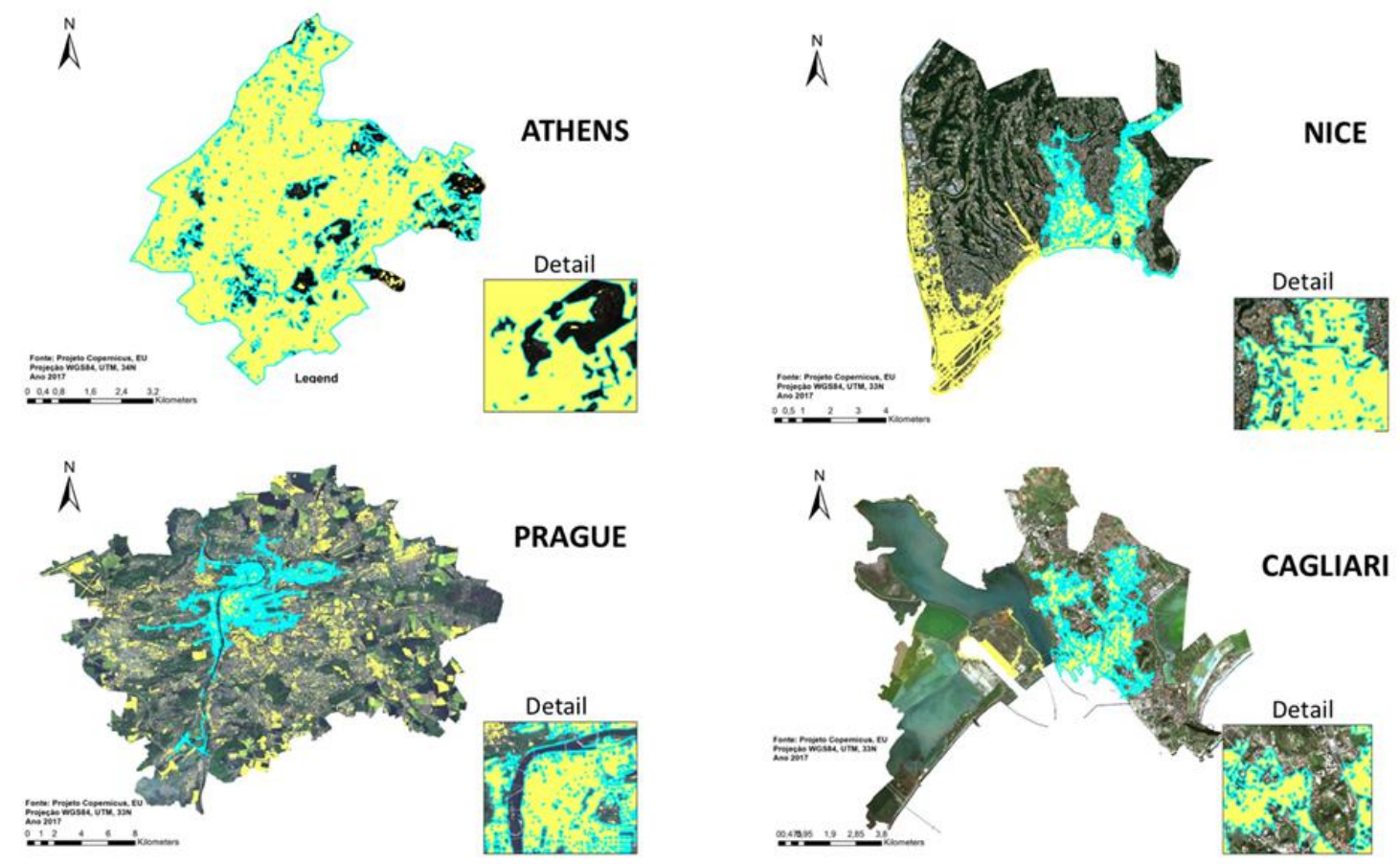

Source: Prepared by the authors.

The study of metrics and forms based on the proposal of Landscape Ecology can be improved to find new references to be proposed in urban master plans. Metrics of connectivity can be very useful to find ecological corridors. Even been two-dimensional, they can be very useful in the studies of urban parameters, but they can be even more interesting if combined with three-dimensional information, about the height of vegetation cover, so that references of vegetation volumes can be used to reach the equilibrium with built volumes.

Discussing the results, we emphasize the difficulties in making comparisons and the risks of indexes. Rankings must be avoided, but if indexes are proposed, it's quite important that they make clear that they are models. Models are simplifications of reality, defined according to specific goals and approaches. It was also very important to see that in most case studies we cannot work with administrative definitions, borders or references, because they may have reasons that are not related to spatial analysis. 
It's time, with all the conditions allowed by technologies of geoinformation, to test new indexes, but to avoid rankings. A ranking can only be accepted if it considers local specificity and justified by a clear reason. A rank cannot be a reductionist, but may produce "alternatives", in plural, according to different points of view. It's time for more than one answer instead of a single map. It's time for plurality in cartography.

It's important to defend the free access to data, as the example of Copernicus project, and the possibilities allowed by Sentinel Imagery. Data can be transformed into information, which can result in knowledge.

We could also see that studies based on the metrics of Landscape Ecology can be very useful, and they are much more robust then simplifications generally used. Future studies must go deeper in discussing the importance of considering local references, to perform relative and not absolute studies about green areas. In the next steps we must discuss the role of vegetation cover and analyze it according to the typology uses.

Once again it was important to select the main plot of urban use. The main urban plot has a very complex form, in a good relation perimeter/area that tells about the edge factor. And inside the main urban fragment, there are many fragments of vegetation cover, which means that people have access to green areas in their daily lives. The study confirms the information we had about Prague being a reference of best practices in distribution of green areas in the city (Figure 19).

To present a synopsis about the results from the case studies, the main outcome is about the role of morphology and the metrics, showing the advantages of using it in comparison to general indexes and rankings generally presented in studies about vegetation cover and green areas. If we were not using the simple metric of perimeter/area, the edge effect, we could not recognize the differences between some municipalities and the real conditions to the citizens to stay in contact with green areas. In some of them the general vegetation index could be understood as good, resulted from the rate of urban area and vegetation area, but without analyzing if these green 
areas were accessible in daily life. Also in the scale of inside the fragments it was possible to identify these relations.

Figure 19 - The main built area, fragment without vegetation. The spread fragment, very connected to areas of vegetation, and the many urban fragments in the municipality.

Built area - main fragment without vegetation - Prague

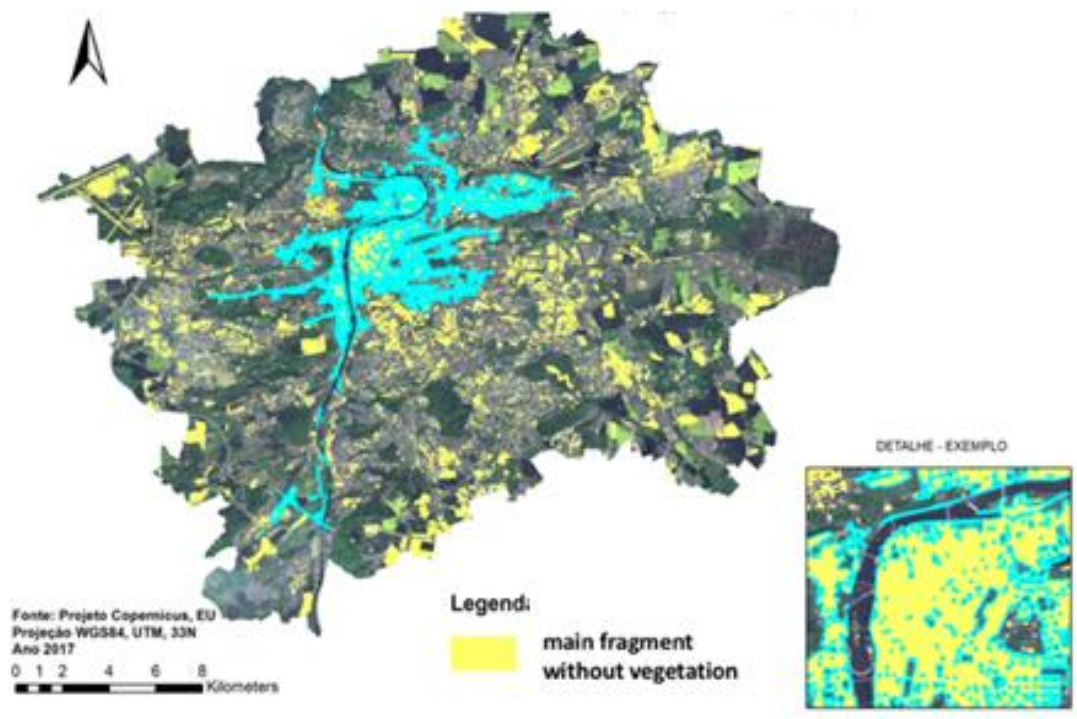

Source: Prepared by the authors.

A sketch, using the language of forms, helps to understand the importance of working with metrics, even with the simplest one and based on two-dimensional analysis. In future case studies it will be also interesting to test other metrics, like the fractal rate, the area core and the ones related to connectivity to identify stepping stones and proximity between fragments (Figure 20).

Figure 20 - Sketch about the distribution and formats of built and vegetation fragments, and the results in integration urban and green areas. Examples of Athens, Prague, Cagliari and Nice

Rev. Bras. de Cartografia, vol. 70, Edição Especial "XXVII Congresso Brasileiro de 


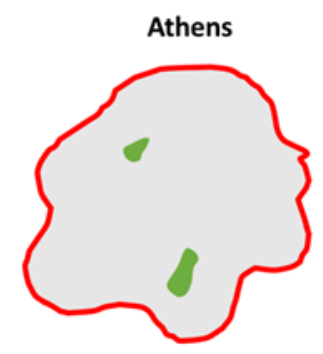

Very dense built area with compact vegetation fragments. Low rate perimeter/area.

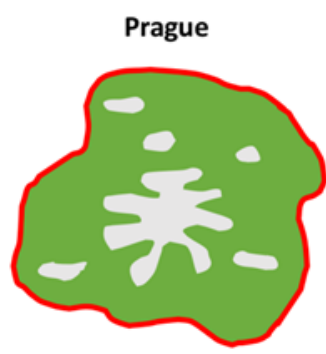

Diffuse built areas
surrounded by
vegetation
fragments. One main
urban fragment.
High rate
perimeter/area.

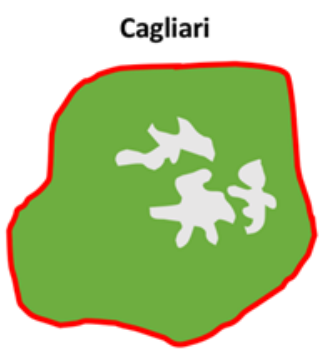

Diffuse built areas surrounded by vegetation fragments. More than one main fragment. High rate perimeter/area.

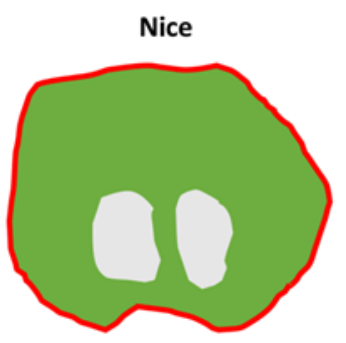

Compact built areas with less contact with vegetation areas. More than one main fragment.

Low rate perimeter/area.

Source: Prepared by the authors.

The main discussion was about the problems of using general indexes to construct rankings, questioning in which conditions some of those indexes could be used, and what the main problems are related to indexes. Even criticizing some general indexes and the logic of rankings, it was possible to understand that studies about the relation between built and green landscape must be done, to develop some specific urban indexes that could be included in Master Plans.

As future developments, complementary researches will point out the importance of separating vegetation cover according to uses. The idea is also to identify areas of green infrastructure used as recreational places, as areas to be protected due to environmental fragility due to risks and climate changes, or landscape composition areas and embellishment, or as protected areas to maintain the temperature equilibrium as a mass of vegetation besides masses of built areas. Using the classification of uses and classifications of metrics it will be possible to identify potentialities and attractiveness in distribution of green areas in the city.

\section{Acknowledgements}


We thank CNPq (Conselho Nacional de Desenvolvimento Científico e Tecnológico), process 401066/2016-9, Universal Call 01/2016. With the support of Ph.D. scholarship - CAPES/PDSE (Coordenação de Aperfeiçoamento de Pessoal de Nível Superior / Programa de Doutorado Sanduíche no Exterior).

This paper was first presented in "XXVII Congresso Brasileiro de Cartografia e XXVI Exposicarta" in 2017, Rio de Janeiro, in a reduced version mentioned in bibliography.

\section{References}

BERTALANFFY, L. V. General System Theory. New York: G. Braziller, 1968, 289 p.

CAVAlHEIRO, F.; DEL PICCHIA, P. C. D. Áreas verdes: conceitos, objetivos e diretrizes para o planejamento. In: Congresso Brasileiro de Arborização Urbana, Vitória: CBAU, 1992, pp. 29-35.

CHORLEY, R., HAGGETT, P. Models in Geography. London: Methuen, 1967, 816 p.

COUTO, P. Análise factorial aplicada a métricas da paisagem definidas em Fragstats. Investigação Operacional, v. 24, n. 1, 2004, pp. 109- 137.

DENIG, S. The green city index. Munich: Siemens AG Corporate Communications and Government Affairs, 2012, $47 \mathrm{p}$.

FORMAN, R.T.T., GODRON, M. Landscape Ecology. New York: John Wileye Sons, $1986,619 \mathrm{p}$.

LI, X., ZHANG, C., LI, X., RICARD, R., MENG, Q., ZHANG, W. Assessing streetlevel urban greenery using Google Street View and a modified green view index. Urban Forestry e Urban Greening, v. 14, n. 3, 2015, pp. 675-685.

MCHARG, I. Design with nature. New York: American Museum of Natural History, 1969, $197 \mathrm{p}$.

METZGER, J. P. O que é Ecologia de Paisagens? Biota Neotrópica , n.1, 2001, pp. $1-9$. 
MOURA, Ana Clara M., ROCHA, Nicole A., SENA, Ítalo S., KECHAGIOGLOU, Xeni. The role of vegetation cover indexes in urban areas: a contribution based on Landscape Ecology using Sentinel-2 satellite images. Anais do XXVII Congresso Brasileiro de Cartografia e XXVI Exposicarta, SBC, Rio de Janeiro, 2017, pp. 1150-1155.

PREFEITURA MUNICIPAL DE SÃO PAULO. Lei N ${ }^{\circ}$ 16.603, de 27 de dezembro de 2016. Diário Oficial do Estado de São Paulo. Institui os espaços destinados à cultura denominados Ecopontos Culturais na Cidade de São Paulo e dá outras providências.

PREFEITURA MUNICIPAL DE SÃO PAULO. Revisão da Lei de Parcelamento, Uso e Ocupação do Solo (13.885/04). Caderno 1. Agosto, 2014. Available in: http://gestaourbana.prefeitura.sp.gov.br/wpcontent/uploads/2014/10/236926557-Caderno-1-Revisao-da-Lei-deParcelamento-Uso-e-Ocupacao-do-Solo.pdf

ROCHA, N. A., BORGES, J. L. C., MOURA, A. C. M. Conflitos das dinâmicas de transformação urbana e ambiental à luz da ecologia da paisagem. PARC Pesquisa em Arquitetura e Construção, v. 7, n. 1, 2016, pp. 23-34.

ROCHA, Nicole A., SENA, Ítalo S., CASAGRANDE, Pedro B., CASTRO, Marina M., FONSECA, Bráulio M., MOURA, Ana Clara M. Studies of Volumetric Relation Between Vegetation and Buildings Using LIDAR Data and NDVI to Propose Urban Parameters. Revista Brasileira de Cartografia, v. 69, n. 8, 2017. Edição Especial "Geovisualização, mídias sociais e participação cidadã: apoio à representação, análise e gestão da paisagem”, pp.1456-1475.

SOCIEDADE BRASILEIRA DE ARBORIZAÇÃO URBANA - SBAU. "Carta a Londrina e Ibiporã”. Boletim Informativo, v.3, n.5, 1996, p.3.

SEIFERLING, I., NAIKC, N., RATTI, C., PROULX, R. Green streets: Quantifying and mapping urban trees with street-level imagery and computer vision. Landscape and Urban Planning, n. 165, 2017, pp.93- 101. 